\title{
Development and Growth through Economic Diversification: Are there Solutions for Continued Challenges Faced by Brunei Darussalam?
}

\author{
*Shamim Ahmad Siddiqui ${ }^{1}$, Alaa Aldin Abdul Rahim Al Athmay ${ }^{2}$ \\ ${ }^{1}$ Hamdan Bin Mohammed e-University Dubai, UAE \\ ${ }^{2}$ University of Sharjah, Sharjah, UAE \\ *siddiqui51@yahoo.com
}

\begin{abstract}
Since its independence in 1984, the government of Brunei Darussalam has made economic diversification as its prime economic agenda to decrease its heavy dependence on oil and gas industry. The oil and gas industry has significantly contributed in the present level of economic prosperity of this small nation of 0.4 million people. However, being a very capital intensive industry it offers few job opportunities. The majority of the local population relies on better paid government jobs in the non-oil sector. As the rate of growth of new employment opportunities created in the public sectors remains far lower than the rate of growth of local labor force, more and more people must be employed by the private sector. However, a small private sector largely consisting of small service enterprises paying lower wages fails to attract local labor force. The result is a continuous increase in the rate of unemployment among locals now standing at over $12 \%$. This paper will review government's efforts in diversifying its economy to reduce its vulnerability in revenue generation and create jobs for its increasing labor force. Based on a review the paper will suggest some possible solutions that could be considered by the government and the civil society of Brunei Darussalam.
\end{abstract}

Keywords: Brunei Darussalam, Economic Diversification, Economic resources, Unemployment, Economic Policy

\section{Introduction}

The state of Brunei Darussalam lies on Borneo's north western coast close to vital sea lanes through South China Sea linking Indian and Pacific Oceans. It is a mere enclave of 2226 square miles (5,765 square kms) with a small population of 401, 890 (July 2011; estimated). The country is enclosed on the landward side by Sarawak, one of the eastern provinces of Malaysia. Brunei Darussalam resumed its international responsibility as a fully independent and sovereign nation shortly after midnight on 31st December 1983, after almost 100 years of British protection.

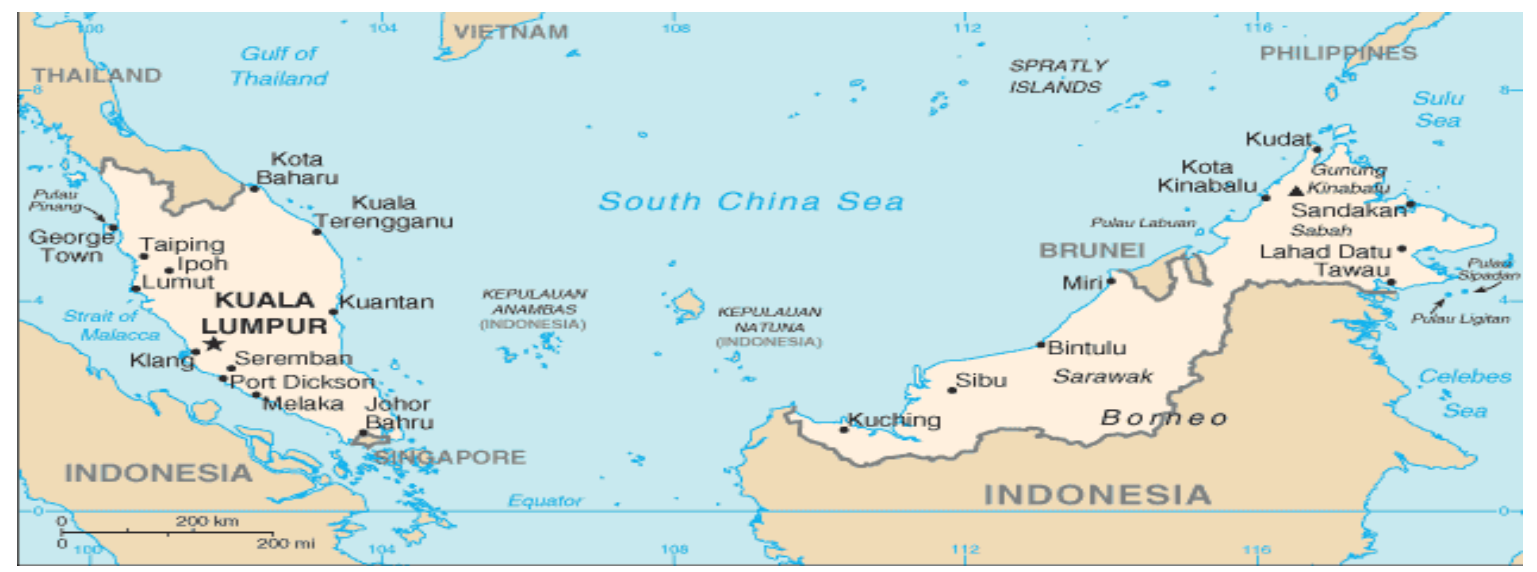

Although much reduced from former glory --- the sultans of Brunei once controlled the whole of Borneo and part of the Philippines --- this tiny state has proved to be very fortunately located on the oil and gas prospective western littoral of Borneo. Though Brunei is not often considered when the main beneficiaries of the post 1973 oil price rises are discussed, in fact it ranks as one of the most providential states of all where actual government 
spending is regularly under budget. In the year 2010, per capita GDP (in international dollars) was \$48, 892 (IMF, 2011) However, relatively large level of revenue coming from export of oil and gas has also made the country too dependent on oil. Furthermore, it has also caused the wage rate and the cost of living much higher than all of its neighboring countries, which have made it less attractive for both local and foreign investors (Siddiqui, et al, 2006). Since its fifth five year national development plan (1986-1990), the first after independence, the government of Brunei Darussalam has consistently proclaimed the diversification of its economy as a prime objective. There were three obvious reasons for achieving these objectives: (i) to reduce dependence on oil and gas thus reducing economic vulnerability that is a common problem of many small states (ii) to find alternate and additional source of revenue for the government and (iii) to create jobs for an increasing number of people joining the labor force of the country. However, several factors made diversification of the economy a difficult challenge. The small size of the economy, lack of skilled and unskilled workers, higher wages and cost of materials compared to most of the neighboring countries, were some of the severe hindrances that were quite difficult to tackle. In order to foster economic growth, a number of suggestions were made to pick and develop some key industries for the country such as banking and finance, information technology, tourism, shipping and communications, and chemicals and refineries. None of these, however, could take off due to various reasons mentioned above. The unemployment rate among local population has kept growing continuously irrespective of the fluctuations in the international prices of oil, and sizable international reserves the country has been able to maintain.

Among many things positive, Brunei has remained an extremely peaceful country with strong family values among all ethnic and religious communities of the country. The government spends substantial amount of money in providing free education and health facilities to its citizens, and permanent residents most of them Chinese migrants who came to the country during the British protective era and their descendents. Thanks to a huge foreign exchange reserves, Brunei has been able to maintain interchangeability of its currency with Singapore dollar since 1967, the year Singapore established its Board of Commissioner of Currency. Singapore government peruses a policy of stable currency through 'managed float' against a basket of currencies of its major trade partners. The stability of Singapore currency, Brunei's policy of liberal trade regime and a comfortable foreign exchange reserves position has kept inflation at very low levels. Low industrialization has kept its air and water clean and a vast forest reservoir makes this small country an ever green land. The heavy dependence of the economy on oil and gas and an increasing level of unemployment has, however, remained a chronic problem for the country. Are there any possible solutions for Brunei's elusive goal of diversification? After all, there are other small nations, which are able to achieve economic diversification with or without availability of mineral resources. An excellent example is Dubai, which was able to diversify its economy before its oil reserves were used up. Same is the case of Bahrain, which had little mineral resources to start with but was able to establish a vibrant financial sector. On the other hand, Singapore, a much smaller country than Brunei, with no oil and gas or any other mineral or agricultural resources was able to establish one of the most enviable economies of the world. This paper is an attempt to suggest reasons for the failure of all government attempts in diversifying Brunei's economy. We think it is extremely important to know these reasons. Apparently, the government seems to be quite serious about the goal and instigated a number of studies by foreign consultants to chalk out a course of action. However, no new actions by the government are seen, implying one of the two things; either the government is not serious about diversification or all the suggestions are un-implementable. The plan of the paper is as follows. In section two, we describe the methodology adopted for this paper. Section three provides information on the resource base of the economy. Section four presents a review of literature on the economy of Brunei. The next section gives some important and relevant statistics for the country. Section six looks at the most recent vision and goals set by the country for the next 30 years. In section seven we present an overview of what had been planned and achieved since country's independence followed by our understanding of the reasons for some of the failures. Finally, in section eight we give some recommendations that could either lead to diversification or minimize the need to diversify the economy. Section nine contains some concluding remarks.

\section{Methodology}

This paper uses a kind of cognitive heuristic method to deduce policy options for Brunei Darussalam in its quest to achieve the goal of economic diversification. First, we briefly look at the resource base of the country and analyze the pattern of sectoral contribution of GDP in the overall macroeconomic environment over the years. This provides an appropriate background to present a review of literature on the economy of Brunei. We then 
look at government of Brunei's most recent pronouncements for the future in dealing with its cherished but elusive goal. Our method neither involves any survey nor does it apply any sophisticated technique of statistical inference of the secondary data that was primarily available through government publications. The advantage of the method used here is that it is fast and fugal. In our view, one of the possible reasons for Brunei's failure to achieve economic diversification could be due to some veiled constraints. We brave to divulge these constraints and provide and explain our suggested options.

\section{Resource Base of Brunei Economy}

Oil \& Gas: Since the discovery of the first oil field in 1929, oil and gas are the backbone of the Brunei economy. Despite a decline over the years (83.7\% of GDP in 1980 and 72.2\% in 1985), its contribution to GDP was 57.2 in 2007. While in the later half of 1980s, oil production was pegged at around 150,000 barrels per day, production of oil has often fluctuated with price of oil in the international markets. It peaked at 219 thousand bpd in 2006 and stood at 170 thousand bpd in 2010 (IMF County Report, 2011, P.19). The Brunei Shell Petroleum (BSP) in which the Brunei government is the equal partner with Royal Dutch Shell Company, has seven off shore and two on shore oil fields. Another active concession holder is Jasra-Elf, which commenced operation actively a few years ago. Almost $90 \%$ of its oil comes from off shore fields. The country is also rich in natural gas production. In year 2010, it produced 12.46 billion cubic meters. It has a long term contract to export gas in liquefied form mainly to Japan (IMF Country Report 2011, P.19). It is the world's fourth largest producer of Liquefied Natural Gas (LNG), which is mainly exported to Japan. A second 20 year contract was signed in 1993 between Cold Gas of Brunei LNG and three Japanese companies. Under this new contract, Brunei Shell will supply 5.54 million tons of LNG per annum to three Japanese power company_ Tokyo Electric Power, Tokyo Gas and Osaka Gas. Brunei's LNG plant at Lumut which is one of the largest in the world was upgraded and expanded in 1993 at a cost of $\mathrm{B} \$ 100$ million. Revenue from LNG produce is almost as significant as oil in the export and royalty profile of the state since the late 1970s (Lawrey and Siddiqui, 2006). Revenues from the hydrocarbons sector account for nearly half of gross domestic product (GDP), around 90 percent of merchandise exports, and 80 percent of government revenues. Brunei consumes little energy domestically (16,000 bpd in 2009) (CIA Fact Book on Brunei, May 2011) and is a sizeable net exporter of oil and natural gas. However, the country's hydrocarbon reserves have declined over the last several decades. The bulk of Brunei's domestic energy consumption comes from natural gas, while the balance is met by oil. As oil and natural gas reserves are further depleted, there may be some pressure to diversify the country's energy consumption mix. According to Oil \& Gas Journal (OGJ), Brunei's oil reserves are declining and stood at 1.1 billion barrels of proven oil reserves as of January 2007. To prolong the life of Brunei's hydrocarbon reserves, the government controls oil production levels. During 2006, Brunei produced an estimated 220,000 barrels per day (bbl/d) of oil, of which 198,000 bbl/d was crude oil and the remainder was natural gas liquids. Crude oil production peaked at about $240,000 \mathrm{bbl} / \mathrm{d}$ in 1979 , but the government's conservation efforts have mostly kept output under 200,000 bbl/d since that time. In 2006, Brunei consumed an estimated 13,000 bbl/d of oil, with most of the country's crude oil production exported to other countries in the region. Despite Brunei's status as a net exporter of oil, the country imports about half of the refined petroleum products that it consumes, since it has limited domestic refining capacity (Energy Information Administration, January 2009).

Territorial Disputes Limit E\&P Activities: Despite ongoing exploration and production (E\&P) activities, industry sources expect that onshore and coastal areas of Brunei are unlikely to hold significant additional oil reserves. The most promising acreage lies in deepwater areas in the South China Sea, although an ongoing territorial dispute with neighboring Malaysia has limited E\&P work in these areas. Brunei awarded offshore Blocks J and K to consortia led by Shell and Total in 2000. However, these companies suspended exploration work following an April 2003 incident in which several naval patrol boats from Malaysia chased away a Total ship. Malaysia has extended its territorial claims into seas that Brunei says are in its Exclusive Economic Zone (EEZ). Also in 2003, Malaysia's PETRONAS and partner Murphy Oil logged a significant oil find in the Kikeh Block, which the companies estimate holds 700 million barrels of recoverable oil reserves. Brunei officials claim that the Kikeh find extends into Bock J in Brunei's territory (for more information, see the Malaysia Country Analysis Brief and the South China Sea Regional Analysis Brief (Energy Information Administration, January 2009). 
Downstream Activities: According to $O G J$, Brunei had 8,600 bpd of refining capacity at one facility as of January 2007. BSP operates the country's lone refinery at Seria. According to industry sources, this refinery meets about one half of Brunei's domestic petroleum product needs. Brunei must import small amounts of petroleum products from neighboring countries to meet domestic demand. Brunei's government subsidizes refined fuels for domestic consumption. Brunei exports most of its natural gas production. According to OGJ, Brunei held 13.8 trillion cubic feet (Tcf) of proven natural gas reserves as of January 2007. Most of Brunei's natural gas reserves are from associated fields, occurring alongside the country's crude oil deposits. In 2004, Brunei produced 406 billion cubic feet (Bcf) of natural gas while consuming 71 Bcf. During 2004, Brunei exported $357 \mathrm{Bcf}$ of liquefied natural gas (LNG), of which 88 percent went to Japan and the remainder went to South Korea. Brunei became the first Asian exporter of LNG in 1972. Brunei is an important regional producer of LNG, with 2005 exports totaling 333 Bcf, or 6.8 million metric tons (MMt). In 2005, 92 percent of Brunei's LNG exports were sent to Japan, with the rest going to South Korea. BLNG operates the country's sole natural gas liquefaction plant and LNG export terminal, located at Lumut. The facility has a total capacity of 7.2 MMt/y (350 Bcf/y), and BLNG has announced plans to add a new production train with $4.0 \mathrm{MMt} / \mathrm{y}$ (195 Bcf/y) of additional capacity. While the planned expansion has been discussed at length, there are no firm agreements in place that guarantee the production train will be built (Energy Information Administration, January 2009). The pattern of oil and gas reserves is difficult to evaluate because of lack of access to confidential data. According to a new estimates, the new finds by Brunei Shell and development made by Jasra-Elf, have extended the life of Brunei's oil at the current level of production to 70 years. Other conservative estimates claim that the known reserves will exhaust in 27 years. On the other hand, a proven natural gas reserve at the current rate of production is expected to last for another forty years (Lawrey and Siddiqui 2006). The revenue generated by the sale of oil and gas has resulted in budget surplus over the years, which have been invested in foreign countries that generate a substantial amount of income. The government of Brunei owns a 579,000 hectare cattle ranch in Australia, which is bigger in size than Brunei (Lawrey and Siddiqui 2006).

Agriculture, Forestry and Fishing: The agro economy contributed just over $2 \%$ to GDP in 1993. The country has to import $80 \%$ of its food requirements. Although land, finance and irrigation are all available and the government has established model farms to train potential farmers, the scarcity of labor has failed to increase agricultural output and achieve even a very modest target for rice production (18\% of the total requirement). A large supply of meat is imported from Sultanate's cattle ranch in Australia. There is a great potential for the development of orchards as there is a wide variety of fruits available in the country. Large scale less labor intensive, mechanized fruit plantation could be a great success (Lawrey and Siddiqui 2006).

Forestry: Forests are considered Brunei's most permanent assets. About $81 \%$ of total land area of 5765 square kilometers is covered with diverse forest types such as mangrove, peat, swamp, heath, and mixed dipterocarp and montane. Fifty eight percent of the country is under primary forest cover. Unlike the other neighboring countries, forests have not been fully exploited for timber and other commercial uses due to the availability of revenue from hydro carbon resources. Forestry exports are prohibited by law. Under strict control of the authorities, timber production is limited to 100,000 cubic meter per annum for local consumption (Lawrey and Siddiqui 2006).

Fisheries: Although Brunei has one of the highest consumption of sea food, and a sizable potential, its total annual sea food production was only 1, 726 tones which is short of its local needs. Large areas have been identified suitable for shrimp, prawn, and fish culture. In the sixth five year national development plan (199095), 28 million dollars have been allocated for the development of this sector (Lawrey and Siddiqui 2006).

\section{Literature Review}

Kong Tse and Fernandes (1991) raised a number of interesting questions about countries possessing exportable oil and gas deposits: Does the oil industry function as a leading sector and gradually induces the development of other related industries; Does the increase in income enlarge the size of the domestic market leading to economies of scale and eventually leading to the diversification; and whether the Government uses the vast sum of petro-dollars to build-up a broad and expanded economic base? One can easily observe that for none of three questions posed, an affirmative answer is possible in case of Brunei Darussalam. According to Ali (1992) Brunei's economic policy has, since the beginning of its Fifth National Development Plan (1986-90), been directed towards three objectives (Ali, 1992, p.196) 
- Diversification via industrialization,

- Industrialization via privatization, and

- Privatization via Bruneization

Ali however claimed that that progress in achieving these goals had been much slower than expected. He suggested that if the government of Brunei had to select industries to sponsor prior to exhaustion of its hydrocarbon reserves, that it might consider the composition of its imports. Ali argued that some imported goods could be economically produced in Brunei with prospects of limited exports in some cases. In his view, there were some products for which scale economies would not be an important limitation. Import substitution could have been possible especially under a restrictive import policy. However, the government of Brunei along with Singapore has always advocated freer trade regimes in ASEAN forums. Brunei has also been very receptive to World Bank and IMF who have remained steadfast against the idea of import substitution. The government did try, however, to provide considerable amount of subsidy for increasing rice cultivation. Nevertheless, the local rice production has remained insignificant to this date. Clearly and Wong (1994) noted increase in some agricultural tropical crops such as fresh fruit and vegetables production of which has expanded recently. It is fair to suggest that this was made possible with the influx of imported farm workers from Indonesia. Since the independence in 1984, the government of Brunei has raised the standard of living with provision of free health and education, high salaries for government employees, low domestic prices for oil, gas and local landline calls, housing grants and interest free housing loans, old age pensions, etc. Moreover, it has been continuously investing proceeds of surplus budget in foreign countries, thanks to the rent generated by the hydrocarbon sector. Tisdell (1997) suggested Brunei, like other mineral-rich exporting countries, needed to make decisions about how much of its rental income to invest abroad and how much to allocate to its domestic economy and in what way. This allocation could have important consequences for employment and incomes in Brunei (Tisdell, 1997). Tisdell (1997) also discussed the issue of investing the rental income and the mechanism of distributing the same. He also looks at the consequences of spending that rental income within Brunei through improving infrastructure and wage subsidy to the locals working in the private sector.

Cleary and Wong who stated also highlighted the importance of this issue, 'Much of Brunei's excess revenue is banked rather than invested in development, and held overseas rather than domestically (Clearly and Wong 1994, p.100). There is little doubt that if part of such funds were invested in Brunei in industries that could generate linkages, bring in technology transfer and develop export potentials, the benefits and multipliers to the country would be considerable'(Clearly and Wong 1994, p.100). Kotler et al., (1997) maintained that there is no single prescription that all countries should follow in order to build their wealth and national welfare as different countries' endowment and the paths they have undertaken resulted in different growth performance. For these reasons, they have suggested a systematic methodology that each country can apply. This includes an assessment of their existing economic environment, opportunities, strengths and weaknesses, by which the most promising pathways to achieving growth and economic revitalisation can be identified. They suggested the need to develop a nation's strategic postures that include developing the right investment policies, building on its industrial clusters, and developing its national industrial portfolio, trade policies and macroeconomic policies, infrastructure and institutional framework. For Brunei Darussalam, the new long-term development plan (LTDP) has listed eight development strategies and each one of them is accompanied by several policy directions. However, whether they will succeed or not is not clear, as policies made by the same authorities did not bring fruits in the past. In Brunei Darussalam: Developing Within Its Own Paradigm, a paper contributed to Southeast Asian Affairs by Duraman and Hashim (1998), it was noted, "There are some areas where government could use its influence and others where it should allow the 'invisible hand' of the market to determine resource allocation." They further argued, "Since development from Brunei's perspective incorporates essential values, high economic growth itself is considered meaningless if undermined by frequent social unrest and political instability. Such a situation can create tension and compromise Brunei's development objectives." Duraman (1994) and Duraman \& Hashim (1998), Opai (2008), Yunos (2009) and Lawrey (2010) have made their assessments of the extent of achievement of the objective of economic diversification and discussed the impediments and challenges faced by Brunei Darussalam.

According to Hashim (2010), Brunei's economic structure continues in many respects to be similar to that in the 1970s and even earlier. For him, there is no paucity of ideas and initiatives but still one can observe the significant contribution of the oil and gas sector to the economy. For him, the biggest challenge for Brunei Darussalam is how to attract and congregate investors in sectors that promote diversity and the sustained benefits derived from 
them. He stresses that lessons from economies such as Singapore and the UAE can enlighten the nation about the need to focus and invest more in areas that relate to both macro and microeconomic management (Hashim 2010, P. 30). Hashim refers to FDI Confidence Index Survey of 2009 that praises the authorities of Dubai in accomplishing the confidence of investors who have expressed their deep appreciation of Dubai's conducive policies for doing business, access to best-in-class infrastructure, advanced logistics facilities and safe environment. The related challenges for Brunei Darussalam in this respect are its small market size and the small size of the non-oil private sector (Hashim, 2010). Kotler et al (1997) maintained that there is no single prescription that all countries should follow in order to build their wealth and national welfare as different countries' endowment and the paths they have undertaken resulted in different growth performance. For these reasons, they have suggested a systematic methodology that each country can apply. This includes an assessment of their existing economic environment, opportunities, strengths and weaknesses, by which the most promising pathways to achieving growth and economic revitalisation can be identified. They suggested the need to develop a nation's strategic postures that include developing the right investment policies, building on its industrial clusters, and developing its national industrial portfolio, trade policies and macroeconomic policies, infrastructure and institutional framework. For Brunei Darussalam, the new long-term development plan (LTDP) has listed eight development strategies and each one of them is accompanied by several policy directions (Hashim, 2010). However, whether they will succeed or not is not clear, as policies made by the same authorities did not bring fruits in the past.

Macroeconomic Environment: Despite the completion of the last five five-yearly development plans, the basic structure and characteristics of the economy have, largely, remained the same. For a closer and meaningful look the economy could be essentially divided into three main sectors;

- Oil \& gas,

- Non oil and gas government sector, and

- Non-oil \& gas private sector.

Table 1: Contribution of Oil and Non-Oil Sectors (1986-2008) (in millions Brunei dollars)

\begin{tabular}{|c|c|c|c|c|c|c|c|c|}
\hline \multirow[t]{3}{*}{ Year } & \multicolumn{2}{|c|}{ GDP } & \multicolumn{2}{|c|}{ Oil \& gas Sector } & \multirow{2}{*}{\multicolumn{2}{|c|}{$\begin{array}{l}\text { Non Oil \& Gas } \\
\text { Govt. Sector }\end{array}$}} & \multirow{2}{*}{\multicolumn{2}{|c|}{$\begin{array}{l}\text { Non Oil \& Gas } \\
\text { Private sector }\end{array}$}} \\
\hline & \multirow[t]{2}{*}{ Value } & \multirow[t]{2}{*}{$\%$ of GDP } & \multirow[t]{2}{*}{ Value } & \multirow[t]{2}{*}{$\%$ of GDP } & & & & \\
\hline & & & & & Value & $\%$ of GDP & Value & $\%$ of GDP \\
\hline 1986 & $5,135.6$ & 100 & $3,062.6$ & 59.6 & $1,110.3$ & 21.6 & 962.7 & 18.7 \\
\hline 1987 & $5,800.9$ & 100 & $3,566.5$ & 61.5 & $1,152.4$ & 19.8 & $1,083.0$ & 18.7 \\
\hline 1988 & $5,414.8$ & 100 & $2,884.1$ & 53.3 & $1,317.4$ & 24.3 & $1,213.3$ & 22.4 \\
\hline 1989 & $5,845.0$ & 100 & $3,033.7$ & 51.9 & $1,375.4$ & 23.5 & $1,435.9$ & 24.6 \\
\hline 1990 & $6,508.6$ & 100 & $3,490.7$ & 53.6 & $1,436.6$ & 22.1 & $1,581.3$ & 24.3 \\
\hline 1991 & $6,620.5$ & 100 & $3,334.7$ & 49.6 & $1,655.7$ & 25.0 & $1,630.1$ & 24.6 \\
\hline 1992 & $6,565.1$ & 100 & $2,983.5$ & 45.4 & $1,754.0$ & 26.7 & $1,827.6$ & 27.8 \\
\hline 1993 & $6,585.1$ & 100 & $2,753.3$ & 41.8 & $1,845.3$ & 28.0 & $1,986.5$ & 30.2 \\
\hline 1994 & $6,686.2$ & 100 & $2,541.3$ & 38.0 & $1,916.6$ & 28.7 & $2,228.3$ & 33.3 \\
\hline 1995 & $7,394.2$ & 100 & $2,862.6$ & 38.7 & $2,190.7$ & 29.6 & $2,340.9$ & 31.7 \\
\hline 1996 & $7,408.6$ & 100 & $2,686.3$ & 36.3 & $1,905.0$ & 25.7 & $2,817.3$ & 38.0 \\
\hline 1997 & $7,628.1$ & 100 & $2,991.7$ & 39.2 & $1,713.2$ & 22.5 & $2,923.2$ & 38.3 \\
\hline 1998 & $6,534.0$ & 100 & $2,139.2$ & 32.7 & $1,763.9$ & 27.0 & $2,630.9$ & 40.3 \\
\hline 1999 & $7,144.7$ & 100 & $2,668.1$ & 37.3 & $1,783.6$ & 25.0 & $2,673.0$ & 37.4 \\
\hline 2000 & $10,346.0$ & 100 & 5950.4 & 57.5 & 1586.2 & 15.3 & 2809.4 & 27.2 \\
\hline 2001 & $10,035.4$ & 100 & 5352.3 & 53.3 & 1709.6 & 17.0 & 2973.5 & 29.6 \\
\hline 2002 & $10,463.1$ & 100 & 5531.6 & 52.9 & 1710.2 & 16.3 & 3221.2 & 30.8 \\
\hline 2003 & $11,424.2$ & 100 & 6530.2 & 57.2 & 1688.9 & 14.8 & 3205.1 & 28.1 \\
\hline 2004 & $13,305.8$ & 100 & 8236.4 & 61.9 & 1785.3 & 13.4 & 3284.0 & 24.7 \\
\hline 2005 & $15,864.1$ & 100 & $10,540.4$ & 66.4 & 1847.0 & 11.6 & 3476.4 & 21.9 \\
\hline 2006 & $18,370.2$ & 100 & $12,635.3$ & 68.8 & 2008.5 & 9.1 & 3726.2 & 22.1 \\
\hline 2007 & $18,458.4$ & 100 & $12,332.9$ & 66.8 & $2,239.4$ & 12.1 & $3,886.1$ & 21.1 \\
\hline 2008 & $20,397.9$ & 100 & $14,300.0$ & 70.1 & $2,152.2$ & 10.6 & $3,945.7$ & 19.3 \\
\hline 2009 & $15,611.4$ & 100 & 9417.0 & 60.3 & 2189.7 & 14.0 & 4004.6 & 25.7 \\
\hline
\end{tabular}

Brunei Govt. Statistical year Books, 2009 
Table 1 shows that the share of oil and gas in nominal GDP was 59.6 and 61.5 in 1986 and 1987. The corresponding values in Brunei dollars were 3, 062.6 and 3,566 millions. Since then it continuously declined until 1998-99. In 1999, it contributed 2,668.1 but its share in GDP was only $37.3 \%$. The reason was simple; the non-oil \& gas sectors government and private sectors were steadily increasing (and continue to do so) irrespective of the fluctuations in the international prices of oil and gas. The growth and size of the non-oil sector is primarily driven by the increase in population and the range and quality of services provided by different government departments. Similarly, the increasing population and corresponding increase in disposable income expands the size of non-oil \& gas private sector. In 2009, the latest year for which the data is available for, the amount contributed by the oil and gas sector stood at 9417.0 which was $60.3 \%$ of GDP, much lower than its peak of $14,300.0$ (70.1 \% of GDP) in 2008. The declining international prices of oil and gas does not have significant impact on government spending as the country has invested a sizable amount of revenue generated from oil in foreign countries. The figures of annual income from these investments are not revealed publicly and they are not included in annual government budget documents. It can be safely assumed that any deficit in annual budget is financed through income generated through these investments. ${ }^{1}$

Table 2 shows the contribution made by different subsectors of the non-oil\& gas sector. Manufacturing of apparel and textile sector that contributed 250 million Brunei dollars in 2002 with a share of $2.37 \%$ in GDP decreased to 80 million ( $0.5 \%$ of GDP) in 2009 . The main reason of this decline was the end of international quota system in early 2005 that curbed exports from countries like China and India but had attracted foreign manufacturers mostly from Singapore to establish their factories in Brunei. Many of them later shifted their Brunei units to Vietnam. In 2009, the share of the agricultural sector remained at $0.8 \%$ of GDP at a meager value of 141.9 million Brunei dollars. Despite government subsidy given to the rice producers, the country is unable to compete with Thailand, the main exporter of rice to Brunei. ${ }^{2}$ As the table shows wholesale, retail trade, business services and finance are other important non-oil \& gas sector contributors to the economy.

Table 2: Contribution of Sub-Sectors of Non-Oil Sector (in millions Brunei \$)

\begin{tabular}{|c|c|c|c|c|c|c|c|c|}
\hline & \multicolumn{2}{|c|}{2002} & \multicolumn{2}{|c|}{2005} & \multicolumn{2}{|c|}{2008} & \multicolumn{2}{|c|}{2009} \\
\hline & Value & $\%$ & Value & $\%$ & Value & $\%$ & Value & $\%$ \\
\hline GDP & 10463 & 100 & 15864 & 100 & 20397 & 100 & 15611 & 100 \\
\hline Oil \& gas sector & 5531 & 52.9 & 10540 & 66.4 & 14300 & 70.1 & 9417 & 60.3 \\
\hline Non-oil \& gas Sector & 4931 & 47.1 & 5323 & 33.6 & 6097 & 29.9 & 6194 & 39.7 \\
\hline Government & 1710 & 16.3 & 1847 & 11.6 & 2152 & 10.6 & 2189 & 14.0 \\
\hline Private & 3221 & 30.8 & 3476 & 22.0 & 3945 & 19.3 & 4004 & 25.7 \\
\hline \multicolumn{9}{|l|}{ Sub Sectors of Non oil \& gas sector } \\
\hline Vegetables, fruits \& other agriculture & 22.5 & 0.20 & 23.6 & 0.1 & 29.9 & 0.1 & 29.3 & 0.2 \\
\hline Livestock \& poultry & 35.8 & 0.40 & 34.8 & 0.2 & 46.2 & 0.2 & 51.7 & 0.3 \\
\hline Forestry & 4.2 & 0.04 & 5.3 & 0.0 & 6.6 & 0.0 & 6.7 & 0.0 \\
\hline Fishery & 52.0 & 0.50 & 86.4 & 0.5 & 46.9 & 0.2 & 54.2 & 0.3 \\
\hline Manufacturing of apparel \& textile & 247.9 & 2.37 & 197.3 & 1.2 & 103.2 & 0.5 & 80.0 & 0.5 \\
\hline Other manufacturing & 84.6 & 0.81 & 82.7 & 0.5 & 64.9 & 0.3 & 73.5 & 0.5 \\
\hline Electricity \& water & 92.3 & 0.88 & 113.3 & 0.7 & 115.0 & 0.6 & 122.0 & 0.8 \\
\hline Construction & 390.7 & 3.73 & 418.5 & 2.6 & 534.4 & 2.6 & 518.1 & 3.3 \\
\hline Wholesale \& retail trade & 403.4 & 3.86 & 457.8 & 2.9 & 558.0 & 2.7 & 591.2 & 3.8 \\
\hline Water transport & 109.1 & 1.04 & 143.3 & 0.9 & 145.5 & 0.7 & 161.1 & 1.0 \\
\hline Air transport & 118.8 & 1.14 & 115.7 & 0.7 & 114.3 & 0.6 & 123.9 & 0.8 \\
\hline Other transport services & 34.9 & 0.33 & 44.1 & 0.3 & 108.5 & 0.5 & 105.6 & 0.7 \\
\hline Communication & 162.6 & 1.55 & 153.4 & 1.0 & 165.2 & 0.8 & 165.4 & 1.1 \\
\hline Finance & 352.2 & 3.37 & 472.3 & 3.0 & 593.2 & 2.9 & 573.8 & 3.7 \\
\hline Real estate \& ownership of dwellings & 406.4 & 3.88 & 412.1 & 2.6 & 433.3 & 2.1 & 429.9 & 2.8 \\
\hline Hotels \& restaurants & 62.2 & 0.59 & 58.2 & 0.4 & 57.5 & 0.3 & 72.2 & 0.5 \\
\hline Private health \& education services & 54.9 & 0.52 & 105.7 & 0.7 & 100.1 & 0.5 & 126.8 & 0.8 \\
\hline Business services & 477.6 & 4.56 & 462.0 & 2.9 & 524.3 & 3.0 & 614.9 & 3.9 \\
\hline Domestic services & 47.4 & 0.45 & 50.2 & 0.3 & 51.9 & 0.3 & 51.9 & 0.3 \\
\hline Other private services & 61.9 & 0.59 & 39.7 & 0.3 & 51.2 & 0.3 & 52.5 & 0.3 \\
\hline Government services & 1710.2 & 16.35 & 1847.0 & 11.6 & 2152.2 & 10.55 & 2189.7 & 14.0 \\
\hline
\end{tabular}

\footnotetext{
${ }^{1}$ Or, by selling of some of the invested assets held abroad.

${ }^{2}$ Rice is the main staple food of Brunei.
} 
Table 3: Direction of Loans by Commercial Banks, 2005-10 (in millions of Brunei \$)

\begin{tabular}{lrrrrrr}
\hline Year & $\mathbf{2 0 0 5}$ & $\mathbf{2 0 0 6}$ & $\mathbf{2 0 0 7}$ & $\mathbf{2 0 0 8}$ & $\mathbf{2 0 0 9}$ & $\mathbf{2 0 1 0}$ \\
\hline Total Loans & 5,932 & 5,819 & 6,036 & 6,113 & 5577 & 5,845 \\
Agricultural & 35 & 30 & 31 & 37 & 28 & 28 \\
Construction & 501 & 555 & 495 & 503 & 446 & 442 \\
Credit \& finance & 14 & 22 & 44 & 29 & 33 & 31 \\
General commerce & 533 & 521 & 561 & 603 & 590 & 593 \\
Manufacturing & 164 & 180 & 179 & 146 & 149 & 144 \\
Personal Loans & 4,078 & 3,834 & 3,675 & 3,635 & 3497 & 3,435 \\
Mortgages & 741 & 820 & 1,014 & 1,190 & 1038 & 1,038 \\
Other & 3,337 & 3,014 & 2,661 & 2,445 & 2459 & 2,397 \\
Professional Services & 68 & 81 & 79 & 90 & 93 & 96 \\
Transport & 539 & 596 & 972 & 1,070 & 741 & 1,076 \\
\hline Source IMF Country report on Brof
\end{tabular}

Source: IMF Country report on Brunei June, 2011.

Table 3 shows the direction of loans of commercial banks during 2005 and 2010. The major head of loan has been personal loans, mostly used for car financing, marriage, pilgrimage to Mecca and house building. It is quite clear that manufacturing and general commerce do not get the significant share of bank loans. There are only three locally owned commercial banks in Brunei and these are the only banks that are incorporated in the country. Majority shares of two of them are held by the government of Brunei. The third, Baiduri Bank is a private bank. Major foreign banks operating in Brunei are HSBC, Citi Bank, Standard Chartered and May Bank. These banks are unable to utilize their funds in Brunei and are allowed by the government to transfer them abroad.

Table 4 below shows composition of government revenue. It clearly shows how the government of Brunei is dependent on the revenues generated by its oil and gas sector. The country has no personal income tax and profits of oil and gas companies are the dominant source of corporate income tax (the current rate of corporate income tax in Brunei is 30\%). Moreover, oil and gas sector is also the main contributor of non-tax revenue as corporations in this sector have to pay royalties (rent) to the government. As the government also is the major equity holder in major companies in this sector, it also receives substantial income in terms of dividends. Import tax, primarily on motor vehicles and tobacco, and income generated through telecommunication companies under government monopoly are the other significant sources of non-tax revenue. An important source of income missing in Table 4 is the income generated through investment by the government in foreign countries detail of which is publicly not available.

Table 4: Composition of Government revenue (in millions Brunei \$)

\begin{tabular}{lrrrrrr}
\hline & $\mathbf{2 0 0 4 / 0 5}$ & $\mathbf{2 0 0 5 / 0 6}$ & $\mathbf{2 0 0 6 / 0 7}$ & $\mathbf{2 0 0 7 / 0 8}$ & $\mathbf{2 0 0 8 / 0 9}$ & $\mathbf{2 0 0 9 / 1 0}$ \\
\hline Total Revenue & 6,404 & 8,484 & 9,310 & 10,042 & 11,378 & 6,393 \\
Tax Revenue & 3,685 & 5,241 & 5,575 & 6,345 & 7,434 & 3,739 \\
Taxes on net income \& profits & 3,563 & 5,099 & 5,452 & 6,176 & 7,275 & 3,579 \\
Corporate taxes & 3,560 & 5,095 & 5,447 & 6,169 & 7,271 & 3,573 \\
Oil \& gas production companies & 3,439 & 4,980 & 5,300 & 6,029 & 7,105 & 3,326 \\
Other companies & 121 & 116 & 147 & 140 & 165 & 247 \\
Individual (estate duties) & 0 & 0 & 1 & 0 & 0 & 1 \\
Stamp duty & 3 & 4 & 4 & 6 & 4 & 5 \\
Taxes on international trade & 108 & 125 & 104 & 151 & 140 & 141 \\
Motor vehicle tax & 62 & 64 & 50 & 68 & 76 & 67 \\
Tobacco & 21 & 22 & 22 & 23 & 21 & 22 \\
\hline
\end{tabular}




\begin{tabular}{|c|c|c|c|c|c|c|}
\hline Others & 25 & 39 & 33 & 60 & 43 & 52 \\
\hline Taxes on goods $\&$ services & 14 & 16 & 18 & 19 & 19 & 19 \\
\hline Nontax Revenue & 2,719 & 3,243 & 3,735 & 3,696 & 3,944 & 2,654 \\
\hline Property income & 2,419 & 2,880 & 3,465 & 3,235 & 3,669 & 2,359 \\
\hline Oil sector & 2,376 & 2,796 & 3,302 & 2,812 & 3,446 & 2,264 \\
\hline Oil \& gas royalties & 662 & 854 & 942 & 992 & 1,089 & 727 \\
\hline Dividend paid by oil companies & 1,714 & 1,941 & 2,360 & 1,820 & 2,356 & 1,537 \\
\hline Other & 43 & 84 & 163 & 422 & 223 & 95 \\
\hline \multicolumn{7}{|l|}{ Administrative fees $\&$ charges } \\
\hline Sales of goods \& fines & 297 & 361 & 267 & 458 & 271 & 291 \\
\hline Telecom \& utilities & 217 & 275 & 159 & 343 & 154 & 168 \\
\hline other & 79 & 86 & 109 & 114 & 117 & 123 \\
\hline Other Nontax revenue & 3 & 3 & 3 & 4 & 4 & 4 \\
\hline \multicolumn{7}{|l|}{ Memorandum items: } \\
\hline Oil \& gas sector revenue & 5,815 & 7,775 & 8,602 & 8,841 & 10,551 & 5,590 \\
\hline Nonoil revenue & 589 & 709 & 708 & 1,200 & 827 & 803 \\
\hline 0il\& gas as a $\%$ of total revenue & 91 & 92 & 92 & 88 & 93 & 87 \\
\hline
\end{tabular}

Source: Brunei statistical year book, 2009. Brunei’s fiscal year runs through April to March.

Table 5: Composition of Government Expenditure and Budget Balance

\begin{tabular}{|c|c|c|c|c|c|}
\hline \multirow[t]{2}{*}{ Total expenditure } & 2003-04 & $2005-06$ & 2007-08 & 2008-09 & 2009-10 \\
\hline & 5,748 & 5,153 & 6,020 & 5,975 & 6,639 \\
\hline Current & 4,596 & 4,126 & 4,878 & 4,957 & 4,685 \\
\hline Wages and salaries & 1,785 & 1,496 & 1,683 & 1,718 & 1,750 \\
\hline Other charges annually recurrent & 1,751 & 1,431 & 1,776 & 1,689 & 1,722 \\
\hline Charged & 1,060 & 1,199 & 1,419 & 1,549 & 1,213 \\
\hline Pensions & 288 & 270 & 325 & 350 & 373 \\
\hline Royalties payments & 673 & 833 & 992 & 1,084 & 716 \\
\hline Others & 98 & 97 & 102 & 116 & 124 \\
\hline Capital & 1,151 & 1,026 & 1,142 & 1,018 & 1,954 \\
\hline Other charges Special expenditure & 765 & 538 & 534 & 423 & 1,057 \\
\hline Development expenditure & 360 & 488 & 608 & 595 & 897 \\
\hline Investment in public enterprises & 26 & 0 & 0 & 0 & 0 \\
\hline Total revenue & 6,369 & 8,484 & 10,042 & 11,378 & 6,393 \\
\hline Total expenditure & 5,748 & 5,153 & 6,020 & 5,975 & 6,639 \\
\hline Primary budget surplus & 622 & 3,331 & 4,021 & 5,403 & -246 \\
\hline Total revenue excluding royalties & 5,735 & 7,630 & 9,049 & 10,289 & 5,666 \\
\hline Total expenditure excluding royalties & 5,074 & 4,320 & 5,028 & 4,891 & 5,923 \\
\hline Primary budget surplus excluding royalties & 661 & 3,310 & 4,021 & 5,398 & -257 \\
\hline Non-oil revenue 1 / & 820 & 709 & 1,200 & 827 & 803 \\
\hline Non-oil expenditure 2/ & 5,074 & 4,320 & 5,028 & 4,891 & 5,923 \\
\hline Non-oil primary balance & $-4,254$ & $-3,611$ & $-3,827$ & $-4,064$ & $-5,120$ \\
\hline $\begin{array}{l}\text { Sources: IMF country report June } 2011 . \\
\text { Data provided by the Brunei authorities; and IM } \\
1 \text { / Excludes energy sector corporate taxes, roya } \\
\text { 2/ Excludes disbursements of royalties. }\end{array}$ & $\begin{array}{l}\text { estimate } \\
\text { nd divide }\end{array}$ & & & & \\
\hline
\end{tabular}

Brunei follows April-March fiscal year 
Table 5 shows the unique way the government of Brunei constructs its annual budget. Other charges special expenditure is a significant amount detail of which is unavailable. We can observe that during 2003-04 and 200809 the country has substantial primary budget surplus and primary budget surplus excluding royalties. It is obvious that all the royalties received is transferred accordingly. For example the amount received and spent as royalties in 2009-10 were B 727 and 716 million respectively. Primary budget surplus excluding royalty, therefore, seems to be the appropriate indicator of government budget surplus. One caveat, however, is the omission of income generated through investment abroad; the budget moves to negative territory if the international price of oil and gas decline to a certain level. Thus, we observe that the global economic slowdown produced a negative primary budget surplus excluding royalties of $B \$ 257$ million in 2009-10. If the income accrued on investment made abroad was considered, it is unlikely government would experience a budget deficit. It is interesting to note the figures for non-oil primary balance, which has always been substantially negative depicting the reliance of economy on oil revenue as well as economic vulnerability.

\section{Table 6: Brunei Darussalam Public Sector Employment}

\begin{tabular}{llllllll}
\hline Year & $\mathbf{2 0 0 0}$ & $\mathbf{2 0 0 2}$ & $\mathbf{2 0 0 4}$ & $\mathbf{2 0 0 6}$ & $\mathbf{2 0 0 7}$ & $\mathbf{2 0 0 8}$ & $\mathbf{2 0 0 9}$ \\
\hline Total government employees & 39,704 & 41,066 & 42,191 & 43,515 & 44,777 & 46,091 & 46,757 \\
$\begin{array}{l}\% \quad \text { Change in total govt. } \\
\text { employment }\end{array}$ & 4.4 & 3.5 & 1.7 & 0.1 & 2.0 & 2.9 & 1.4 \\
\hline
\end{tabular}

Tables 6 and 7 show the number of employees in public and private sectors of the economy. The number of government sector employees is continuously increasing at a slow pace. Over the years, the government has made concerted efforts to gradually decrease foreigners in the public sector. Unlike the gulf countries, most foreign workers in the government sector were well educated and mostly employed as school and college teachers and medical doctors. As more and more locals graduated from universities, at home and abroad, most foreign teachers working in public schools have been replaced. The country still depends heavily on foreign medical doctors for its expanding and improving free health facilities to its citizens. The country also has four small universities, which have sizable number of foreign faculty. While dependence on foreign professionals has reduced to less than 7\%, private sector still relies heavily on foreign workers. In 2009 out of 121, 158 workers in the private sector, more than 82 thousand were foreigners. Bulk of these workers is employed in the construction, manufacturing and services sectors. Foreign workers take up jobs that are either menial or low paid and compared to government jobs less attractive to local workers. Table 8 depicts the official unemployment rate in Brunei Darussalam from 1991 to 2010. However, the way official rate of unemployment is estimated has several problems and is far from satisfactory. The apparently low level of unemployment rate is thus misleading.

Table 7: Brunei Darussalam: Private Sector Employment (2009)

\begin{tabular}{lllll}
\hline & $\begin{array}{l}\text { Total } \\
\text { Employees }\end{array}$ & $\begin{array}{l}\text { Employees as \% } \\
\text { of total } \\
\text { employment }\end{array}$ & $\begin{array}{l}\text { Citizens and } \\
\text { Permanent } \\
\text { Residents }\end{array}$ & $\begin{array}{l}\text { Temporary } \\
\text { Residents }\end{array}$ \\
\hline Agriculture, forestry, and fishing & 4,955 & 4.1 & 1,285 & 3,670 \\
Production of oil and natural gas & 6,154 & 5.1 & 4,237 & 1,917 \\
Sawmilling and timber processing & 796 & 0.7 & 131 & 665 \\
Other mining, quarrying, and & 13,020 & 10.7 & 2,929 & 10,091 \\
manufacturing & 33,591 & 27.7 & 3,906 & 29,685 \\
Construction & 21,091 & 17.4 & 8,382 & 12,709 \\
Wholesale and retail trading & 11,934 & 9.8 & 3,602 & 8,332 \\
Coffee shops, restaurants, and hotels & 6,106 & 5 & 2,816 & 3,290 \\
Transport, storage, and communication & 9,728 & 8 & 6,777 & 2,951 \\
Financial, insurance, and business & 13,783 & 11.4 & 4,960 & 8,823 \\
services & 121,158 & 100 & 39,025 & 82,133 \\
Community, social, and personal services & &
\end{tabular}

Source: IMF country Report June 2009. Labor Department, Annual census of employers \& employees, 2009: Ministry of Home Affairs. 
Table 8: Unemployment level in Brunei Darussalam

\begin{tabular}{lllllllll}
\hline Year & $\mathbf{1 9 9 7}$ & $\mathbf{1 9 9 9}$ & $\mathbf{2 0 0 1}$ & $\mathbf{2 0 0 3}$ & $\mathbf{2 0 0 5}$ & $\mathbf{2 0 0 7}$ & $\mathbf{2 0 0 9}$ & $\mathbf{2 0 1 0}$ \\
\hline Unemployment Rate & 1.745 & 10.244 & 4.045 & 2.846 & 2.892 & 3.409 & 3.748 & 3.748 \\
\hline
\end{tabular}

Source: IMF 2010 World Economic Outlook as quoted by Index Mundi, http://www.indexmundi.com/brunei/unemployment_rate.html. Accessed on August1, 2011.

Calculation of unemployment rate: Brunei Darussalam uses the following universal formula to calculate its rate of unemployment.

Number of people Unemployed X 100

Total Labor Force

However using this formula can be misleading for a country that significantly depends on foreign workers. While all the unemployed would be necessarily locals, including foreign workers in the denominator of this formula will make the unemployment rate lower, not revealing the level of unemployment among local labor force. Other problem in calculating the true level of unemployment is the number of unemployed people. The Labor Department, which is responsible for providing this number, uses number of people who register themselves in a particular year with the department's employment bureau to seek a job. As not many people are able to get a job through this bureau, not all those who are employed would register themselves. In addition, those who registered in previous years and still not having a job are not included. On the other hand, those who are taken as unemployed people for a particular year may already have got a job! In the absence of any unemployment benefit, the only reliable figure of unemployment rate is available every ten years through population census. In 2001 census, the unemployment rate among local labor force was found to be $12 \%$ (Government of Brunei Population Census 2001) whereas the unemployment rate given in the statistical yearbook for that year was 4.04\% (Table 7 above). Analysis and results of population census due in 2011 are currently under process. A true picture of unemployment is expected soon. We conclude this section by noting two basic economic problems faced by Brunei Darussalam; it is over dependence on oil \& gas sector and its inability to provide enough jobs to the increasing local labor force. The government and its economic planners are appeared to be well aware of this situation. The issuance of the ninth five-year plan (supposed to cover the period 2006-2010) was delayed until 2007 to incorporate the guidelines of Vision 2035 as well as to align it with a 10year mid-range economic development plan (2007-2017). Before we provide our thoughts how to stimulate the economy, let us have a look at some of the literature on Brunei.

Brunei Government's plans: In 2006, the government of Brunei Darussalam announced its plans for next 30 years through Vision 2035. It was accompanied by country's $9^{\text {th }}$ five-year plan (2007-12) and a ten year plan. These two plans were made keeping in view the goals set for Vision 2035.

Vision 203516: Before setting the long terms goals for the country, the document described the existing situation of the country as follows:

- Although oil and gas resources have contributed much to the nation's prosperity, economic growth has, overall, not kept pace with population growth.

- The public sector that is the main employer of the majority of the citizens and residents can no longer adequately absorb the growing numbers of young people wishing to enter the work force each year.

- There is a widening gap between the expectations and capabilities of the nation's youth and the employment opportunities currently being created.

- The oil and gas sector that makes up about half of the economy and over 90 percent of export earnings employs less than 3 per cent of the work force.

- The local business community continues to be weak and is unable to create the employment opportunities now required.

- In order to offer its people a bright and prosperous future, Brunei Darussalam must, therefore, adapt to change and all that this entails by way of ambition, innovation and bold planning.

- The challenge facing the nation lies in finding ways to do this successfully whilst, at the same time, upholding the values upon which the nation has developed and progressed. 
The document then stated the following broad goals for the next 30 years:

- An educated, highly skilled and accomplished people

- We will measure our quality of life by reference to the United Nations Human Development Index and aim to be the top 10 nations in the world.

- Our aim is for Brunei Darussalam's per capita income to be within that of the top 10 countries of the world.

- While recognizing the need to change, we will continue to uphold vigorously the values that have been the foundation of our political stability, social harmony and prosperity.

The following eight strategies for Achieving vision 2035 were formulated:

- An education strategy

- An economic strategy

- A security strategy

- An institutional development strategy

- A local business development strategy

- An infrastructure development strategy

- A social security strategy

- An environmental strategy

Before one can contemplate on taking operational steps in line with Vision 2035, it would be quite apposite to contemplate on the outcome of the five-year economic development plans enacted since independence.

What went wrong and what are the possible options? It must be admitted that Brunei has really faced a number of issues and challenges in achieving the goal of diversification. Some of the often-discussed are:

- Small population or small market

- Non Availability of skilled and un-skilled workers

- Relatively high wages

- Lack of Entrepreneurial Skills

However, if we look at some of the small countries of Middle East with similar characteristics as Brunei Darussalam, it could be said that Brunei has failed to chalk out a more aggressive drive to kick start its economy. One reason could be its desire to maintain or not to disturb the peaceful and serene social and physical environment of the country. It is no doubt one of the most peaceful and green countries of the world, if not the most. Over the years, the government of Brunei has committed substantial amount of its revenues into education, health, communications and other infrastructure projects and to some extent in housing. Furthermore, it has prudently invested surplus revenues abroad through government-controlled Brunei Investment Agency. Although the income of BIA is not reported, it is widely believed that its portfolio is well diversified. It is further assumed that any decline of revenue due to downward trend in oil and gas prices in international market would be offset by the income generated by Brunei's investments made through BIA. Briefly, Brunei's prosperity appears to be sustainable. The only potential problem for Brunei is the rising number of unemployed population in the country. There is a need to closely look at the actual size of the people unemployed in the country. The 2007 statistics released in late January 2009 claims that unemployment rate in the country in 2007 was merely $3.4 \%$. This is however seems to be misleading as discussed earlier. Indeed the very strong social structure of the country has kept the unemployment problem under control. However, it cannot continue forever. Eventually the country has to provide more jobs for its expanding labour force. Of course, one viable option would be to equip the potential entrants to labour force with the best possible education and skills so that they may seek job in foreign countries. However, if the government and the society are convinced that diversification is necessary for additional source of government income, reduce economic and financial vulnerability and provide more jobs then it is important to come up with new strategies for attracting local and foreign investments in the country.

Some Thoughts on New Strategies and Target Industries: There is a new recognition of the importance of institutions and institutional change in the process of economic development. The central insight of this new consensus is that markets do not just evolve on their own but that their development and effective functioning is dependent upon the existence of well-structured institutions, including legal, financial, and 
banking systems. In short, it is institutions, which matter, in this new view, not just economic policies, and it is the state that plays an indispensable role in creating the right institutional environment for economic development and sustained economic growth. It is clear from the above analysis that Brunei Darussalam is a country experiencing stable prices, trade and balance of payment surplus, comfortable level of foreign exchange reserves and effectively a sizeable level of budget surplus. All the five-year development plans covering the period after independence (1986-2005) emphasized the need for diversification and industrialization of the country to reduce the dependence on the oil and gas sector as well as to provide job opportunities to an increasingly literate labour force. Specifically, manufacturing, tourism, finance and downstream industries were seen as potential areas for economic development. However, so far no major success has been achieved in the diversification drive. The heavily capital-intensive oil sector itself has its limitation in providing jobs. The government sector expanded rapidly after independence and has been the main source of employment for the locals. However, its ability to continuously create jobs is limited. The unemployment rate is continuously increasing and it could have reached as high as $13 \%$ among local labour force. Apparently, it seems that, in the absence of any formal government social schemes for unemployed labour force, the local society with its values and traditions have absorbed this level of employment through family support. However, the rising gap between the potential and the actual level of GDP could not be overlooked without end. It also has potential to eventually create social tension in an otherwise extremely peaceful and harmonious society. We, therefore, assume that the government is very serious in looking at different options to jump-start the non-oil sector of the economy. Before we look at some specific sectors that could be selected as potential areas for economic growth in the country, it would be quite pertinent to note the following options for the country. With massive reserves and investment made by the government abroad, and the continued effective budget surplus, the government can create a social security system that can sustain this nation of small population (with declining fertility rate) at the current level of prosperity for the foreseeable future. Economic diversification, under this scenario would become less important compared to an efficient management of foreign investment portfolio. The $8^{\text {th }}$ NDP contemplated establishment of a high technology industrial fund by the government to provide loans to local as well as foreign entrepreneurs. The aim of first forming the Brunei Darussalam Economic Council (BDEC) and then the Brunei Economic Development Board (BEDB) was also to accelerate the process of diversification through industrialization.

Several potential sectors that were seen as potential drivers for diversification such as manufacturing, tourism and a financial centre have yet to be developed. We would suggest that thorough investigation should be made to understand the underlying reasons for the slow movements in all these areas. Specifically, one should look into the issues of land entitlement, lack of a clear policy on immigrant labor, slow decisionmaking process of the relevant authorities, corporate tax structure, and possibly a lack of social cohesion on the overall development goals and the means to achieve these goals. Apparently, it seems that the government has to do something very attractive to influence the foreign as well as the local investors to be more involved. For example:

- a drastic reduction in corporate tax rates for most industries in the non-oil sector

- a liberal policy for immigrant labor for all sectors and all types of labor

- establishment of public enterprise for ultimate hand over to the private sector

- an attractive policy on land

- a major shift in visa policy to boost tourism

We understand that not all of these and other policies could be easily adopted. However, a few bold policies seem to be overdue. We now turn to look at some specific sectors of the economy that were supposed to become engines of growth in the economy but so far have remained in their infancy.

Manufacturing20: The only sizeable manufacturing industry in Brunei Darussalam has been the textile industry that saw a health growth in the nineties. However, it was mainly a result of some foreign investors taking advantage of un-utilized textile quota for the European countries and the United States. However, as this industry has largely employed foreign labor and pay very low wages, the impact of the slowdown of this industry will be hardly noticed on market of local labor force or retail businesses.

The insignificant growth of manufacturing sector is largely blamed on:

- Small market

- Labor shortage 
- Labor cost

- Land laws

- Lengthy bureaucratic processes

- Comparable tax advantages

Thorough research and detailed analysis is required to exactly determine the causes of the poor performance of this sector despite continued government emphasis. The country has failed to attract domestic as well as foreign companies to investment in this vital sector. At least the country should have attracted investment in high value adding industries that have less dependence on low cost unskilled foreign labor. The government should take bold actions possibly on land, immigrant labor, tax structure and other areas after doing necessary investigative research. It could be argued that the local population of Brunei may not be in favor of a large influx of foreign workers that may be necessary for a vibrant, diverse and dynamic manufacturing sector. More research should be carried out on this and related issues including foreign labor hiring and wages policies that does not put local labor force in an unnecessary and undesirable disadvantageous position.

Tourism $^{21}$ : The development of the tourism sector as a leading non-oil sector of the economy has been clearly given serious consideration. The Ministry of Industry and Primary Resources has an active department of tourism that receives extended media coverage. The economic benefits of a vibrant tourism sector for any economy are enormous. For Brunei it becomes even more important as it is desperately looking for economic diversification.

\section{Weakness - Obstacles}

- Embryonic tourism industry - Lack of tourism facilities

- Price is expensive in comparison in SE Asia region

- Lack of tourist guide

- Lack of international airline connections

- Very low awareness of Brunei as a tourism destination

- Immigration regulations

\section{Threats}

- Well-established regional competition

- Price competitiveness

- Competition for the cruise market

\section{Opportunities}

- Regional tourism - Gateway to Borneo

- Ecotourism

- Stopover market: for clean tourism such as eco tourism and golf

- Demographic shift

- Cultural tourism

\section{Possible solutions/strategies}

- Enhancing the international awareness of Brunei Darussalam through its consulates and embassies

- The Brunei Tourism Board exploits Royal Brunei Air Lines (RBA) as a partner in spreading international awareness

- Complementing Brunei as a "Gateway to Borneo"

- Creating an image for Brunei Darussalam as a holiday destination

- The implementation of international health and safety standards will ensure the increase of international tour groups who appreciate quality destinations

- Proposing that Brunei exploit various market niches that are experiencing growth: eco-tourism, adventure and cultural tourism, medical tourism, theme parks and cruising

- Enhancing the positioning of Brunei as a leisure destination within the Marketing plan 
- Proposing the program of product development that satisfies the demands of modern holiday travelers

- The use of investment incentives and grants to pump-prime appropriate project development

- Establishing zones for tourism to concentrate and fast-track project investment

- Look into the possibility of liberalizing immigration procedures to facilitate the additional arrival of tourists into Brunei. For example, professionals holding passports of third world countries but having high paid jobs could be issued tourist visa in a reasonable period.

- Proposing a Marketing Plan that targets appropriate markets, in line with the vision of product development

- Encouraging that transit passengers are converted into inbound passengers

- Enhance human resource development

- A program of product development that enhances opportunities for local recreation, as well as for international markets

- A strategy for tourism businesses to give employees training through incentives

- To strengthen the local image of employment in the tourism sector through a local awareness program

- The development of traditional and handicraft industries

It is not difficult to see how much initiative and work is needed if Brunei really wants to become a vibrant tourist destination. It is hoped that the relevant authorities will take quick and bold actions to get Brunei's potential share of the world's tourism industry. The job is difficult but not impossible. Massive investment is needed in creating new products for tourist attraction with or without the involvement of the private sector. An expanding domestic airline will be definitely helpful in attracting more tourists to the sultanate. However, it would not be easy for an airline that has yet to make a profit and has lived through government subsidy since its inception. A further effort is needed in charting out a tourism policy that has general support of all concerned (government, the private businesses and most importantly the local population) towards making the country a competent international tourist destination. Once a decision is made on this issue after a methodical investigation, commensurate policies on target tourists, tourist's products and other tourism facilitating mechanism (such as visa and marketing) should be made and quickly and efficiently implemented.

Brunei International Banking and Financial Centre ${ }^{19}$ : While developing manufacturing and tourism sectors in Brunei may involve decisions that necessitates some compromises and do not have the full support of all sections of the local population, there are few sectors in the economy whose development and growth does not need to address such concerns. Banking and finance in general and Islamic banking and finance in particular being one of them. It is important to realize that in order to become a successful and respectable centre for international banking and finance, a country or region must offer an environment that are conducive and attractive for international businesses. These could be listed as:

- A sizeable domestic financial sector

- A comprehensive regulatory framework

- Competitive tax regime

- Human resources at competitive wages

- Free movement of foreign exchange

- Attractive ownership with profit repatriation regime

A financial centre may also be very successful if it can create a niche market. For example Bahrain is viewed as being well ahead of its rivals in monetary expertise and in terms of regulation, particularly with its efforts to unify the disparate and interpretative regulations of Islamic banking. With 25 Islamic banks, Bahrain is the largest and possibly the best-regulated Islamic financial centre in the world and, although total Islamic bank assets are relatively small, it is generally believed that there is a huge growth potential. Since the establishment of the BIFC, more than 2,500 IBCs have been registered in Brunei Darussalam, the majority of which are conducting significant regional businesses. It is not; however, clear as to how many international companies have actually opened their businesses in Brunei and/or are seriously planning to come to Brunei. The ninth Development plan is expected to reveal the existing situation as well directions for future actions. 
Education ${ }^{20}$ : Another industry that would necessarily get the support of all sections of the society is education. Education is one sector that should have caught the attention of the authorities as one of the most preferred industry Brunei could have developed. The importance of good education for its people has been never overlooked in this country as could be verified by looking at the massive investment government has made in it during the last several decades. However, there does not seem to be an effort to make it an industry and attract large number of foreign students in this country. A government lead and encouragement could have attracted domestic as well as foreign private investment in this sector. Brunei, with its well-known peace and tranquility, could become a very attractive destination for the children of wealthy parents and guardians of developing and less developed countries and in particular those of the Muslim countries. Government should take the lead like different emirates in the UAE who have massively invested in the education sector and succeeded in attracting students from all over the Middle East by providing a class of education not very far removed from the developed world.

\section{Conclusion}

Unlike many developing countries, in many respects, Brunei Darussalam enjoys a very comfortable position. The revenue emanating from its hydrocarbon deposits has not only resulted in a continual trade and effective government budget surplus, it has allowed the country to build up a sizable level of foreign assets and reserves. Its residents do not pay income tax and inflation remains almost non-existent even at times going in the negative range. Education and health care is free for its citizens and permanent residents. Sizable reserves of known hydrocarbon deposits, continuous findings of new ones and the increasing world demand for energy causing international prices to remain high, creates a very glowing picture of the future. The only macroeconomic issues that may have to be tackled by the government is (i) an increasing number of unemployed youths that has kept the country's GDP below its potential levels year after year, and a possible source of social tension and (ii) the economy still heavily dependent on the oil sector. With a local population still below 0.4 million, the country can comfortably continue with the current situation especially if it devises a scheme of unemployment benefit. It would then only need to efficiently manage its foreign portfolio. However, if the country really needs to diversify its economy and / or create jobs for its increasing local labor force, then it has to take appropriate decisions. Needless to mention that, the real wealth of a country is its stock of capital including the human capital.

\section{References}

Ali, A. (1992). Industrialization or Industries? The Vision and the Viability in Brunei Darussalam', in Dato Seri Laila Jasa Awang Haji Abu Bakar Haji Apong (Editor-In-Chief), Sumbangsih UBD: Esei-Esei Mengenai Negara Brunei Darussalam (Essays on Brunei Darussalam), Akademi Pengajian Brunei, Universiti Brunei Darussalam, Brunei Darussalam.

Brunei Statistical Year Book: $(2006,2007,2009)$.

CIA Fact Report: Brunei Darussalam https://www.cia.gov/library/publications/the-worldfactbook/geos/bx.html

Cleary, M. \& Wong, S. Y. (1994). Oil, Economic Development and Diversification in Brunei Darussalam, St. Martin's Press, New York.

Duraman, H. H. I. (1994). Development in Brunei Darussalam: Problems and Prospects of Economic Diversification, in Janang, Akademi Pengajian Brunei, Universiti Brunei Darussalam, Gadong.

Duraman, H. H. I. \& Hashim, H. A. A. (1998). Brunei Darussalam: Developing Within Its Own Paradigm, in Southeast Asian Affairs 1998, Institute of Southeast Asian Studies, Singapore.

Energy Information Administration. (2007). Country Analysis Brief: Brunei, April 2007. www.eia.doe.govt

Hashim, A. A. H. (2010). Challenges in Achieving Wawasan 2035 Goals: Economic Diversification in Perspective. CSPS Strategy and Policy Journal, 1, 29-54.

IMF Country report. (2007). Http://www.imf.org/external/pubs/ft/scr/2008/cr08165.pdf

Kong, T. H. \& Fernandes, N. (1991). Oil and Economic Development in the Sultanate of Brunei, in Sorab Sadri (ed.), Oil and Economic Development, Forum, Kuala Lumpur.

Kotler, P., Jatusripitak, S. \& Maesincee, S. (1997). The Marketing of Nations: Strategic Approach to Building National Wealth, The Free Press, New York. 
Lawrey, R. N. (2010). An Economic Perspective on Economic Diversification in Brunei Darussalam. CSPS Strategy and Policy Journal, 1, 13-28.

Opai, R. (2008). Economic Diversification in Brunei Darussalam: Recent Policy Initiatives and Implementation, in Siew Ee Tan \& Rosnah Opai (eds.), The Economy of Brunei Darussalam: Perspectives and Insights, HBJ Education, Petaling Jaya.

Siddiqui, S. A. \& Lawrey, R. N. (2006). Macroeconomic Framework Paper prepared for the consulting company, Jurutera Tempatan who were responsible for the Second Twenty Year Master Plan (20062025) for Town and Country Planning Department, Ministry of Development, Brunei Darussalam.

Siddiqui, S. A., Hashim, A. H. \& Waheed, A. (1996). Economic and Social Policies of Brunei: An Empirical Analysis. The Philippines Review of Economics and Business, 3, 4-36.

Tisdell, C. (1997). Brunei's Quest for Sustainable Development: Diversification and Other Strategies, Department of Economics, The University of Queensland, Brisbane Queensland Australia. Available at http://espace.library.uq.edu.au/eserv.php?pid=UQ:120477\&dsID=VOL16.pdf

Yunos, R. (2009). The Golden Warisan Brunei Darussalam, 2, Haji Mohd Rozan bin Dato Paduka Haji Mohd Yunos, Bandar Seri Begawan, Brunei Darussalam.2010, World Economic Forum, Geneva. 